\title{
Sustainability of the Bulgarian food processing industry
}

\author{
Nadka KOSTADINOVA, Nadezhda PETROVA, Georgi ALEKSIEV \\ Trakia University, Stara Zagora, Bulgaria
}

\begin{abstract}
:
Aim: The Bulgarian agricultural sector underwent a transformation during the last decade of the 20th century, reducing its economic importance. After accessing the European Union in 2007, Bulgarian producers gained access to this market and reoriented their production. This created important challenges in the supply chain. The aim of this article is to investigate the sustainability of the functioning and development of the food processing industry in Bulgaria. In order to achieve this goal, the following issues are addressed: the state and development of the Bulgarian food industry, the problems and prospects for its sustainable functioning.
\end{abstract}

Design / Research methods: The methods used to solve the tasks are: analysis and synthesis, systematic and structural approach, statistical calculations.

\section{Conclusion / findings:}

While the Bulgarian food processing industry is developing seems to be more sustainable that other industries, scale enlargement and intensification take place. Besides positive and negative tendencies, the authors identify recommendations to foster sustainable development of the industry.

Originality / value of the article: The prospects for the sustainable development of the food processing industry are important for the opportunities for development of foreign markets as a result of the liberalization and globalization of trade, as well as the preservation of the position of the industry in the national market.

Keywords: sustainable development, processing industry, economic relevance

JEL: Q13, Q18, Q57

Correspondence address: Nadka KOSTADINOVA (correspondence author), Trakia University, Stara

Zagora, Bulgaria. E-mail: Nadka Kostadinova: Nadya_kostadinova@yahoo.com (Nadka KOSTADINOVA); nfp@abv.bg (Nadezhda PETROVA); georgi.alexiev@gmail.com (Georgi ALEKSIEV).

Received: 13.01.2019, Revised: 17.07.2019, Revised: 22.10.2019, Accepted: 17.12.2019

doi: http://dx.10.29015/cerem.745 


\section{Nadka KOSTADINOVA, Nadezhda PETROVA, Georgi ALEKSIEV}

\section{Introduction}

The Food and Beverage Industry is a traditional processing industry, one of the oldest in Bulgaria, which occupies an important place in the structure of the national economy. The industry receives raw materials and intermediates from the agrarian sector, processes and produces food and beverages for final consumption or processed materials used as raw materials in other industries.

The food industry has a social significance, since the goods produced by the sector satisfy the daily needs of the population and ensures the normal functioning of the human organism. The established industrial relations with other sectors and its contribution to the stability and development of the national economy are an indication of its economic importance.

The prospects for the sustainable development of Bulgarian food processing industry are in direct connection and dependence not only on the opportunities for development of the foreign markets as a result of the liberalization and globalization of trade, but also on the preservation of its positions in our national market. The aim of the present study is to investigate the sustainability of the functioning and development of the food processing industry in Bulgaria.

In order to achieve the goal, the following issues are addressed: the state and development of our food industry, the problems and prospects for its sustainable functioning. The methods used to solve the tasks are: analysis and synthesis, system and structural approach, statistical calculations.

\section{Sustainable development of Bulgarian food processing industry}

Sustainable development was defined as meeting "the needs of the present generation without compromising the ability of future generations to meet their needs" (WCED 1987). A sustainable food supply would than mean that food will be produced and consumed in such a way, that will not interrupt next generations' food supply (Baldwin 2011). 
The basic challenge in sustainable food production is how to make better use of the available biophysical, and human resources (Stagl 2002). Sustainable development should not be viewed as a stalled process, as a factor mainly of production and consumption. On the contrary, it is dynamic and progressive, based on innovations - from an economic, environmental and social point of view, it has a wide scope for applications. The characterization of sustainable development displays that the managed object is significantly expanded as it is not connected with only one element - economic, environmental, social (Moffatt 1996), but with all three interrelated elements, without emphasizing any of the them.

The production of food products (food, beverages, tobacco) in Bulgaria in 2016 is worth over 5 billion euros or over $5 \%$ of the entire production in the economy. After joining the EU, the Bulgarian Food and Agriculture industry is well adapted to the opportunities of the single market and is developing steadily, more robustly and dynamically than other industries in the country. The value added in the industry for 2015 compared to the base year 2007 increased by over $60 \%$ (Table 1). ${ }^{1}$

The fastest rate of development was reported at the beginning of the survey period (2007), which is related to the accession of the country to the European Union and the inclusion of Bulgarian products in the common market. The second stage of faster growth in value added in the sector was recorded in 2011, which is related to attracting significant foreign direct investment in the sector.

Table 1. Value added at factor cost as at 1 January of the relevant year

\begin{tabular}{|l|l|l|l|l|l|l|l|l|l|}
\hline Indicators & $\mathbf{2 0 0 7}$ & $\mathbf{2 0 0 8}$ & $\mathbf{2 0 0 9}$ & $\mathbf{2 0 1 0}$ & $\mathbf{2 0 1 1}$ & $\mathbf{2 0 1 2}$ & $\mathbf{2 0 1 3}$ & $\mathbf{2 0 1 4}$ & $\mathbf{2 0 1 5}$ \\
\hline $\begin{array}{l}\text { Value added } \\
\text { - million } \\
\text { EURO }\end{array}$ & 592.6 & 777.4 & 843.3 & 805.7 & 903.8 & 870.4 & 927.6 & 915.9 & 950.7 \\
\hline $\begin{array}{l}\text { Dynamics, } \\
\text { 2007=100 }\end{array}$ & 100 & 131.2 & 142.3 & 136 & 152.5 & 146.9 & 156.5 & 154.6 & 160.4 \\
\hline
\end{tabular}

Source: Own calculations based on Eurostat data.

${ }^{1}$ Data presented in this section are based on Eurostat, Ministry of Agriculture, Food and Forestry of Bulgaria, as well as the National Statistical Institute of Bulgaria 


\section{Nadka KOSTADINOVA, Nadezhda PETROVA, Georgi ALEKSIEV}

The value of the production of processed foods for 2016 exceeds EUR 5,705 million (Table 2), incl. food - EUR 4110.5 million; beverages EUR 912.2 million; tobacco and tobacco products - EUR 683.2 million. Compared to 2007, the food industry has produced $42.2 \%$ more goods in 2016. The fastest rate of growth is reported for the food products that occupy the main market share in the sector. The value of the total output of Bulgarian Food and Drink Industry shows a trend similar to that already reported in the value added at factor costs. The fastest the sector is developing at the beginning of the period 2007-2008. This allows us to conclude that the increase in absolute value added is due to an increase in production rather than an increase in productivity in the sector at this stage of its development.

\section{Table 2. Volume of food processing in Bulgaria (million euro)}

\begin{tabular}{|c|c|c|c|c|c|c|c|c|c|c|}
\hline Subtracted & $\mathbf{2 0 0 7}$ & $\mathbf{2 0 0 8}$ & $\mathbf{2 0 0 9}$ & $\mathbf{2 0 1 0}$ & $\mathbf{2 0 1 1}$ & $\mathbf{2 0 1 2}$ & $\mathbf{2 0 1 3}$ & $\mathbf{2 0 1 4}$ & $\mathbf{2 0 1 5}$ & $\mathbf{2 0 1 6}$ \\
\hline $\begin{array}{c}\text { Food } \\
\text { products }\end{array}$ & 2726.3 & 3111.6 & 2999.4 & 3188.3 & 3446.5 & 3534.5 & 3611.9 & 3638.8 & 3836.9 & 4110.5 \\
\hline Drinks & 723.5 & 897.9 & 751.8 & 756.4 & 775.1 & 845.3 & 899 & 836.8 & 853.4 & 912.2 \\
\hline $\begin{array}{c}\text { Tabaco } \\
\text { products }\end{array}$ & 562 & 811.2 & 816.5 & 721.1 & 610.7 & 674.8 & 828.7 & 824.6 & 859.1 & 683.2 \\
\hline \begin{tabular}{c} 
Total: \\
\hline
\end{tabular} & 4011.8 & 4820.7 & 4567.7 & 4665.8 & 4832.3 & 5054.6 & 5339.6 & 5300.2 & 5549.4 & 5705.9 \\
\hline
\end{tabular}

Source: Own calculations based on Eurostat data.

For the period 2007-2016, there is a steady increase in food production and a fall in the production of beverages and tobacco by about $2 \%$. About $4 \%$ of the employed in the Bulgarians economy are employed in the food processing sector in 2016 and its share in the employment in industry is over $18 \%$. Despite the increase in the value of production by the Bulgarian food industry, the number of employed in the sector is decreasing, which is related to the increased efficiency of labor in it.

For the ten-year period under study (2007-2016), the number of employees in food processing industry has been steadily decreasing (close to $16 \%$ reduction in 
2016 compared to 2007), but the value of output for this period has increased by more than $42 \%$. Data show that processing plants have invested more in automated production, resulting in a reduction in the number of employees. These productions, however, require a more skilled labor - and consequently - a higher wage, which leads to an increase in the cost per employee.

The export and import of processed food are of particular importance for the sustainable development of the sector. The size of exports is one of the main indicators of the sustainability and competitiveness of a given sector. From 2007 to 2013 there is a steady trend of export growth in the two food sectors - nearly 3 times for food and tobacco products, while exports of beverages are decreasing (mainly due to the loss of export positions in the wine industry).

After 2013, exports from the food industry show a slight decrease and fluctuations in food products and more significant - in tobacco products - about $16 \%$ compared to 2013 , and for beverages - about $23 \%$. The food group has a major contribution to the export of the food processing industry, with a share of $86.5 \%$ in 2016, the share of tobacco products is $10.5 \%$ and of beverages $-3 \%$. The state and trends of the imports from the food processing industry reveal how much of the demand in the country is satisfied by producers outside the national economy.

\section{Sustainability of the food processing industry and youth employment}

We have concluded so far that Bulgarian food processing industry and agriculture has increased their labor productivity and have been able to produce better economic results with the use of less labor resources. Although labor efficiency is very important for the competitiveness of both sectors it does effect employment rates and thus youth employment in particular.

The employment of young people in agriculture has mixed trends in Bulgaria in the period 2009-2016 as shown on Chart 1. In 2009 more than 15,000 young people (age from 15 to 24) are engaged with the production in the sector, while at the end of the period that number drops to a little over 11,000 with the lowest numbers in 2011 $-7,800$. Significantly larger part of the workforce in agriculture is formed by the 


\section{Nadka KOSTADINOVA, Nadezhda PETROVA, Georgi ALEKSIEV}

group aged 25-34. The trends in the number of people employed in that group follows those in the group 15-24 with a one year delay, which shows the movement of employees from one group to the other, which should be taken in to consideration as well. By the end of the period over 40,000 of the workforce in Bulgarian agriculture are between 24 and 34 years old. The increase in these numbers from 2012 onwards does form a positive trend for the future and inclusion of more young entrepreneurs in the sector, much due to the supporting policy instruments employed by the Common Agricultural Policy of European Union.

\section{Chart 1. Youth employment in the food production and processing industry in} Bulgaria (thousands)

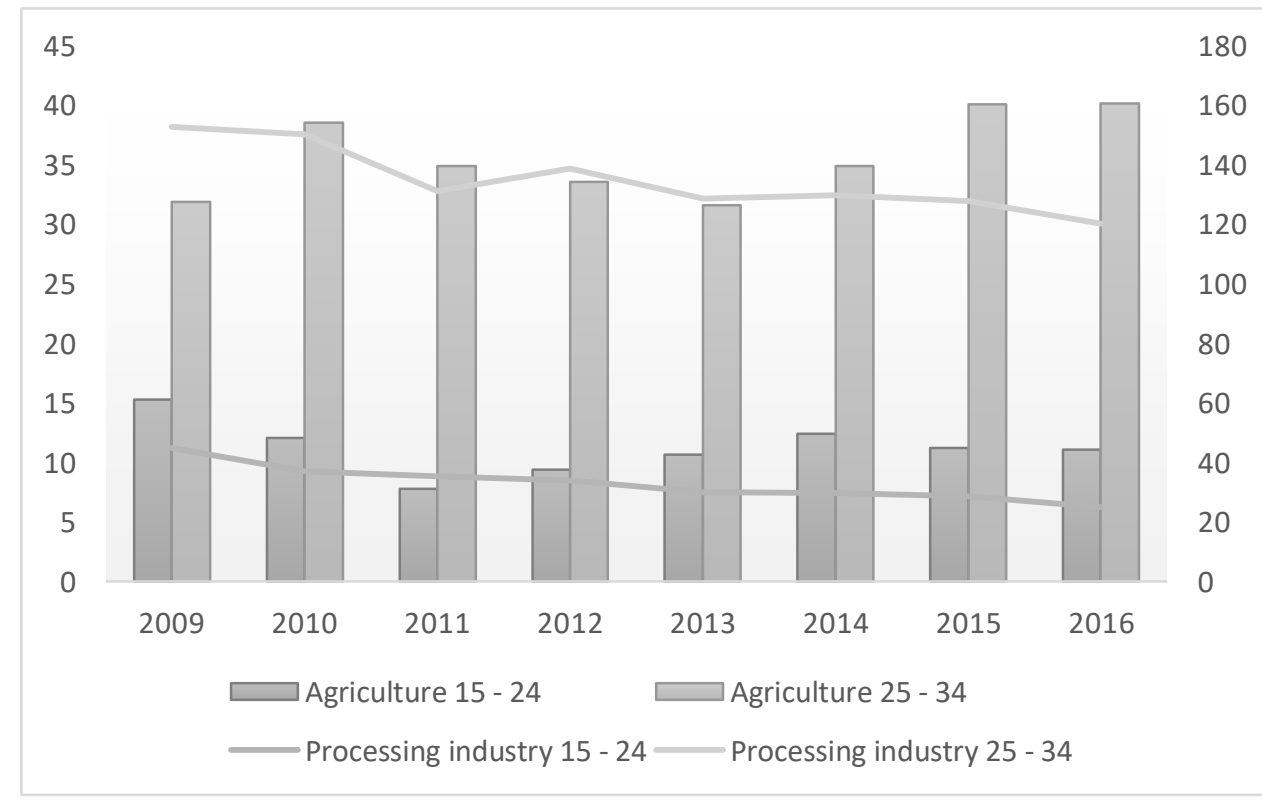

Source: National statistical data.

The trends are vastly different in the processing sector. Unlike the agriculture, where they are mostly positive by the end of the period, here they are clearly negative. In the beginning of the period - 2009 almost 45,000 people aged between 15 and 24 are employed by processing manufacturers. That number drops to almost half by the end of the period - 25000 in 2016. Similar decline is evident in the 
group aged between 25 and 34 years - from 153,000 in 2009 to 120,500 in 2016. The increase in investments by the same enterprises while the employed numbers drop is a clear evidence of increase in labor productivity and decrees in labor requirements. This trend although positive for the enterprises, which improve their competitiveness leads to a decrees in jobs in the sector.

Further studies on the motivation of young people to work in agriculture and the food processing industry is required in order to fully examine the problem.

\section{Concluding remarks}

As a result of the research conducted on the sustainable development of the Bulgarian food industry, several conclusions can be summarized:

- Bulgarian food processing industry is developing and it shows increased sustainably when compared to other industrial sectors - its share in the added value is high and does not intermittently increase;

- The increase in added value has been achieved with fewer employees, which is a positive trend and is evidence of automation and modernization in the industry;

- The steady upward trend in food production is mainly a result of the increase in food production. This is related to these products increased consumption and increase of the purchasing power of the population;

- Competition with importers processing raw materials with a higher level of subsidy has a negative impact on the sector's development.

- In order to improve the conditions for sustainable development of processed food products in Bulgaria, the following recommendations can be formulated:

- The funds foreseen in the Rural Development Program 2014-2020 should focus primarily on food processing and tax incentives to support the investments of the processing enterprises in the treatment of raw materials and thus adding value to them; 


\section{Nadka KOSTADINOVA, Nadezhda PETROVA, Georgi ALEKSIEV}

- Aligning the level of subsidies in agriculture and subsidizing the production of raw materials, that are a priority for Bulgaria (fruits, vegetables, animal products);

- Encourage the participation of Bulgarian processing companies and research organizations in the Horizon 2020 initiatives;

- Stimulation of protected brands - traditional products and provision of support for certification;

- Supporting small businesses in food processing industry to help them meet EU standards and EU requirements;

- Promoting exports to third countries and searching for new markets for traditional Bulgarian products;

- Supporting the export of products for specific market niches on the European and international markets in line with consumer demand for healthy foods, organic food and other high added value foods.

The trends are vastly different in the processing sector. Unlike the agriculture, where they are mostly positive by the end of the period, here they are clearly negative. The increase in investments by the same enterprises while the employed numbers drop is a clear evidence of increase in labor productivity and decrees in labor requirements. This trend although positive for the enterprises, which improve their competitiveness leads to a decrees in jobs in the sector. In order to improve the sustainability of the sector a bigger part of the younger people employed in it should carry relevant degrees to the food processing industry. This is a slowly developing trend, delayed by the lack of adequate educational structures in the country.

The food processing industry occupies a significant share in the country's economy by a measure of value added, people employed, and export value. Its greater adaptability, sustainability and dynamic development make it an industry in the group of priority sectors for the national economy.

\section{References}

Baldwin Ch.J. (ed.) (2011), Sustainability in the food industry, Wiley-Blackwell, Hoboken, NJ.

Kovacheva Ts. (2010), Development and competitive abilities of the food processing industry in the European market, "Economics and Management of Agriculture", vol. 55 no. 2, pp. 3-12. 


\section{SUSTAINABILITY OF THE BULGARIAN FOOD PROCESSINF INDUSTRY}

Malamova N. et. al (2017), Competitive development and price evolution in the food chain in Bulgaria (in Bulgarian), SAA, EIA.

Malamova N. (2014), Competitive potential and factors for the development of the food industry in Bulgaria, "Bulgarian Journal of Economics and Agriculture Management" (in Bulgarian), vol. 59 no. 2, pp. 3-19.

Moffatt I. (1996), Sustainable development. Principles, analysis and policies. Parthenon Publishing Group, Carnforth.

Stagl S. (2002), Local organic food markets. Potentials and limitations for contributing to sustainable development, "Empirica", vol. 29 no. 2, pp. 145-162.

WCED (1987), Our common future, United Nations World Commission on Environment and Development, Oxford University Press, Oxford.

\section{Websites}

Eurostat, http://ec.europa.eu/eurostat

Ministry of Agriculture, Food and Forestry of Bulgaria, https://www.mzh.government.bg/en/

National Statistical Institute of Bulgaria, Industry, Short-Term Business Statistics, https://www.nsi.bg/en/content/4472/short-term-business-statistics

UN Comtrade, https://comtrade.un.org 